\title{
Training and Appointing Processes of School Leaders in Developed and Developing Countries: How is the Situation in Turkey?
}

\author{
Aycan Çiçek Sağlam ${ }^{1, *}$, Ali Geçer², Derya Ba $\breve{g ̆}^{2}$ \\ ${ }^{1}$ Faculty of Education, Muğla Sitkı Koçman University, Turkey \\ ${ }^{2}$ School of Foreign Languages, Muğla Sitkı Koçman University, Turkey
}

Copyright $\bigcirc 2017$ by authors, all rights reserved. Authors agree that this article remains permanently open access under the terms of the Creative Commons Attribution License 4.0 International License

\begin{abstract}
Goal of the study is to compare training and appointing processes of education administrators in developed and developing countries to see similarities and differences and also the situation in Turkey so as to give some suggestion thought to have some positive impacts on training and appointing-related problems of Turkish Education. Within the terms of this main goal, some developed countries such as England, United States, France and Finland as well as some developing countries such as Turkey, Bulgaria, Poland and Hungary have been compared and contrasted in terms of training and appointing processes of education administrators. When taken insight into the results of the study; developed countries except for France have some pre-service training programs and this is a prior requirement to be appointed. When it comes to France, twoyear on-the-job training is needed. Master degree in education management is also a pre-requisite for appointing in developing and developed countries but Turkey and Bulgaria. With the result of the study, it has turned out to be that Turkey hasn't got a pre-service training process among all those countries and the policy for education administrators' choosing and appointing has been changed almost every year over the past 10 years. In addition, it is seen that political interference is frequent thus leading to some conflicts. In view of solving Turkey's education problems in general, training, choosing and appointing processes of education administrators must be regulated in the light of new, permanent and consistent laws.
\end{abstract}

\section{Keywords Education Administrator, Education Administrator Training, Education Administrator Appointing, Education Administrator Training in Developing Countries, Education Administrator Training in Developed Countries}

\section{Introduction}

21 st century not merely provides a wide range of knowledge sources and also ease reaching the knowledge along with the social, political and technological changes, which cause an in increasing competition. This global market making the countries get closer also brings the need to have new approaches so that they catch up with this new era. How to shape and administer education organisations in the centre of those changes are the key issues as well, because a good administration of education organisations makes reaching the expected goals easier and provides a continuous survival in that ambiguous competitive atmosphere.

Reflections by this competition in which individuals need to improve creativity and continuous renewal. De Vita, Colvin, Hammond \& Haycock [1] who has been a scientist in education for years argues that the most important factor that improves the school environment and staff efficiency is the administrator. Therefore, school administrators not just must have qualities and skills to keep up with the change but implement an education role for an effective, strong and productive schools as well (Jackson \& Davis, Olson) [2-3]. A successful administrator is in the centre of the school and his/her knowledge, vision and leadership is the key about how to cope with the problems. Khan [4] suggests that the most significant thing for an organisation is an effective, efficient and trained leader.

Different study results also show how crucial the school administrators must be trained. Studies also stress the importance of training process. For instance; A 10-year comprehensive study by Wallace Foundation conducting studies and projects in the field of education in United States for more 50 years states the first and most significant step is the training process to have strong and effective leaders. According to the report, Mitgang, [5]; School administrator must be educated on purpose and participate pre-service training. Moreover, local authorities must be 
more active and employing administrators having qualities to meet the needs must be supported. Standards to raise a qualitative school administrator, accreditation, certificate programs for administrators and financial supports to the successful administrators, mentorship for new administrators and regional or individual- tailored professional development support are other issues to tackle the problems.

Role of the administrator is very significant at every level of education administration. Globalisation affects administrators as well as education systems. But in Turkey, following the laws and regulations is almost impossible as it changes too often, and consequently, pre-conditions to be an administrator undergoes radical changes as well. Ironically, as any teacher is able to be an administrator and there aren't any objective criteria, some objections even filing lawsuits get widespread.

In literature, some studies investigate current situation with reference to the training appointing process (Altın \& Vatanartıran, Balyer \& Gündüz,) [6-7]. But the attempted coup in Turkey in July 2016 has proven that the process must be handled in a detailed way. For those many of whom were involved in the coup thus harming the country were the teachers and appointed administrators without any objective pre-conditions the ones attempting coup certainly vary from. But when regarded that those people have been educated by teachers and administrator, it is seen how the problem is big in Turkey.

To sum up; it is crucial that training and appointing process are required objective and standard measures so as to solve the problems of education system in Turkey. In especially developed countries, objectivity is the essential part of the school administrator training and appointing process. So the question "how to train and appoint administrators" becomes more of the issue.

Goal of the study is to compare training and appointing processes of education administrators in developed and developing countries to see similarities and differences and also the situation in Turkey so as to give some suggestion thought to have some positive impacts on training and appointing-related problems of Turkish Education. Within the terms of this main goal, some developed countries such as England, United States, France and Finland as well as some developing countries such as Turkey, Bulgaria, Poland and Hungary have been compared and contrasted in terms of training and appointing processes of education administrators

\section{Materials and Methods}

The design of the study is qualitative because the model of the study is qualitative survey model for the purpose of searching how the administrators' training, choosing and appointing processes are in both developed and developing countries and of seeing the current situation in those of
Turkey.

Survey models are research approaches having purposes to describe a certain situation at the time being or in the past. Survey models describe the situation as it is and it is covered suitably to define it (Cohen, Manion \& Morrison, 2011) [8]. In this context; administrator training and appointing processes in develop and developing countries has analysed through survey model to see the current situation and assess with a critical perspective.

Data collecting of the study may be classified as document analysis or research counting on documents. Document-based researches are the ones conducted through analysis of written or online data in resources such as books, newspapers, reports (Büyüköztürk et al., Yıldırım \& Şimşek) [9-10]. A document analysis is the analyses consisting of collected documents when observation and interview are impossible. Thus, these collected documents are searched in view of the researcher (Yıldırım, Şimşek) [10]. This model has been preferred because only documents were benefitted for the purpose of the study.

\subsection{Limitations}

In this study, administrator refers to the administrator in primary and high schools. Higher education or universities are excluded from the study as they are far different from primary and high schools. Resources are the printed ones such as books and essays or online resources on the net.

\section{Discussion}

\subsection{Education Administrator Training and Appointing in Developed Countries}

In this section; education administrators' training and appointing processes in three European countries (England, France and Finland) and United States were observed in the light of OECD Reports.

\subsubsection{Education Leader Training and Appointing in England}

In England, school head teachers are considered to be change pioneers. Hence, it is accepted that they must have the qualities to create education atmosphere, taking the recent improvements into account and must be competent leaders with a coherent notion of education who use management skills. They can also read and direct the change properly. Therefore, a school head teacher must have a manner of administration providing equal opportunities and high purposes and also follow the recent improvements and use these improvements in a view to increasing the standards. Managing the future, being a competent leader of teaching and learning for the organisation as well as having the abilities to self-improve are the keywords for a successful head teacher. Moreover, accountability and responsibility of principles to improve 
the school and the society are regarded to be very important. The head teacher must use these characteristics in harmony with the help of professional knowledge and traits, skills and vision (DfE) [11].

School head teachers are seen as the people of effectiveness and efficiency in England. So, a model which encompasses training, certification, choosing, appointing, orientation and in-service training is followed and implemented fastidiously (Bolam) [12]. As in all developed countries, England also wants to improve the quality of education throughout the country, thereby using some essential standards. As they see the leadership and administration skills are crucial factors leading to a good school, National standards for head teachers is the guideline to be a head teacher. To be a head teacher, the candidates must participate in a training program consisting of theory and practice thus having an effective role to improve administration skills. This certificate program called National Professional Qualification for Headship (NPQH) is managed by National College for School Leadership (NCSL). (Bolam, NPQH) [12-13].

The application, admission and the program itself are also managed cautiously. Vice-head teacher, teachers and education experts can apply for the program and the candidates must have at least 5 -year teaching experience. They must have a reference letter and approval from the head teacher to apply online. This phase is the first election period. The candidates passing the first election process are interviewed online and asked some questions. Afterwards they are sent for workshops and taken 2-day face to face interviews. The last step to be accepted to the program is personality tests. After all, the candidates are invited to paid certificate programs (NPBEA) [14].

NPQH has a four-stage and detailed certificate program to accomplish national goals. The main purpose in the program is to make the candidates improve in direction of their individual needs and skills. The first stage of this 4-12 month program is basic education period. This 180- hour course is obligatory for all candidates and covers the topics of school improvement and strategic leadership. The latter covers and job- based training and administration. The third stage is job- based training and school improvement skills. The last one is the stage in which the candidates aim to construct and improve learning and to be educational leaders. After the program, the candidates present their studies to the board of evaluation and are invited to one-hour interview. The program gets finished successfully if confirmed by Board of Evaluation (NCSL, 2012) [15].

In England appointing head a teacher is taken meticulously just like training period. Head teacher is appointed by a board with at least three members. Unpaid board consists of locals, education experts, school staff, students above 8th class and local authorities with no vote right. The board is responsible of determining the needs of school, finding solutions to the problems, improving the education, regulating the financial budget and also appointing the head teacher. Appointing period takes seven stages (NCSL, 2008). When the head teacher announces that he/she is going to leave, process begins and board of school prepares a report covering the need of school and writes a declaration head teacher position, taking the needs of the school into consideration. Afterwards, they determine suitable candidates and make a pre assessment in terms of NPQH certificate, academic competency, essays on school administration and the situation in previous school. 7-10 candidates are invited to the interview made by six member jury. After the assessment period, head teacher elected is appointed by informing local authorities in writing. Elected head teacher also gives the acceptance letter to the jury and head teacher begins orientation and encouragement (NCSL) [15].

Head teachers join on-the-job training after being accepted to the position. Specialist Schools and Academies Trust (SSAT) which supports new head teachers professionally and makes nationwide sharing is one of those training programs (SSAT) [16]. Leadership Programme for Serving Head teachers (LPHS) is developed by collaborative study of Open University, National College and Hay and McBer. The union's goal is to improve head teachers' qualities and contribute to their Professional developments as well as making the personal development and educational activities (Duncan as cited in Balyer \& Gündüz) [7].

\subsubsection{Educational Leader Training and Appointing in United States}

United States is a pioneer country about training and appointing. Seeing that schools fail to succeed and understanding that head teachers primarily affect school success, almost all states started campaigns for training, choosing and appointing. The reform "No Child behind Act" aiming to leave no child uneducated is another factor to bring up some standards of school leaders' training. Council of Chief State School Officers (CCSSO) and Interstate School Leaders Licensure Consortium (ISLLC) have brought some standards for school leaders and aimed to increase the quality of education. Some new restructure period was started as it had been claimed that the students' success had decreased. For this purpose; some standards for head teachers were launched following the standards of professional development. Moreover, Interstate School Leaders Licensure Consortium (ISLLC) determines common school leader competency standards. Once this common framework was reviewed in 2008 , it begun to be used in all states in order that school leaders would be trained both pre-service and on the job. Common standards of ISLLC are school policies, law, accountancy, curriculum development, public relations and leadership (Mitgang, Hale \& Moorman) [5- 17].

Candidates for the position of school leadership have to participate in a pre-service leadership training in United States in which universities and local authorities cooperate 
with common policies (Hale \& Moorman) [17]. 30-credit program is a master degree for two years. Once the candidates have their master degree of school leadership, they follow a training program with a mentor in schools (Jackson \& Kelly) [18]. School leaders graduating from departments which don't require an obligatory training programs are appointed as a vice-principal just after an on-the-job training (Edelfelt) [19]. Unlike England, United States doesn't have a central Ministry of Education, states' education boards and administrations are responsible for training and appointing. Therefore, school leader training process may vary among different states (Hale \& Moorman) [17]. However, there are some common conditions as well. Bureau of Labour Statistics [20], states that master degree in educational administration or in other fields. In addition, candidates must have a 18-hour basic training. The other pre-conditions are to have worked in state school for 1-3 years and to have administration certificate. There are lots of leadership and administration academies. New Leaders is, for instance, a non-governmental organisation (NGO) which trains school leaders, determines school leadership policies and regulates school systems in the country. The organisation is also the only organisation which raises school leaders. It has two different programs called Aspiring Principles Program and Emerging Leaders Program. New Leaders takes over the responsibility of training school leaders, choosing and appointing. Besides, it develops atmospheres so as to help leaders be successful by conducting bilateral school projects. Both programs under New Leaders are quite selective while determining the candidates for the programs. Thus, they visit schools under the program "New Leaders Urban Excellence Framework" to conduct efficient school and school leader projects in terms of student success (Schleicher) [21].

In addition to New Leaders, universities, councils and foundations such as University of Harvard, New Jersey State University, Arkansas University, The Institute for Educational Leadership (IEL), American Association of School Administrators (AASA), The National Association of Secondary School Principals (NASSP) and The National Association of Elementary School Principals (NAES) involve in school leaders' training period. Moreover, some academy-based national foundations like The National Council of Professors of Educational Administration (NCPEA) and The University Council for Educational Administration (UCEA) are also active in training process. The National Commission on Excellence in Educational Administration (NCEEA), National Policy Board for Educational Administration (NPBEA), New Leaders for New Schools (NLNS), leadership training program, Principle Residency Network (PRN) distance learning program, The Massachusetts Elementary School Principals Association (MESPA) are other examples nationwide (Hale \& Moorman) [17].

There are also other different examples for training of school leaders such as School-University Cooperation and
Peer Assistance and Leadership Program (PAL) which is nationally recognized and non-profit. School-University Cooperation provides free assistance training to the school leaders. In PAL, school leaders meet every two year and exchanges problems and solutions (Meclntyre) [22]. Leaders gather information about their peers and what they have done throughout the year and give a well-structured feedback to them (Anderson) [23].

The employment also differs from one state to the other. Regional Education Offices declare the position publicly and the process starts. Candidates prepare a portfolio along with the reference letter from previous school and the school from which they graduated, diploma, exam result paper from regional office. Afterwards they are interviewed orally or verbally. If the candidate doesn't fail, makes a three-year contract. Regional office could cancel before the end of contract if it were necessary or there were any complaints from either parents or students (Anderson) [23].

\subsubsection{Educational Leader Training and Appointing in France}

Having a central administration system, France as in England and United States defines the success of students as a result of that of school administrator. Therefore, the success of administrator is regarded as a key factor to organisational and individual success (Eurydice) [24].

French Ministry of Education Centre (Condorcet) is responsible for training and appointing in the country. The framework called "Rules related to School Administrator Formation" (Charte de la formation des personnels de direction) and Local Educational Institutes (EPLE) organises the choosing, training and appointing process by coordinating different regions. Candidates must attend 70-80- hour training in two years. After the training period, if they don't fail in the exam, they can be appointed as a school administrator. In some occasions, the appointment can be done by the central or among substitutes. (Eurydice) [24]. In France, appointing primary school administrators and high school administrators differ. The former is not so detailed as the latter. On account of central and hierarchic system, high school administrators have more authorization and responsibilities than those of primary schools (Huber as cited in Balyer \& Gündüz) [7].

Administrator to primary schools in France are not pre-trained but as of 1989, a regional on-the-job training has been managed under 89-122 law codes. The program consists of formal papers about school system and structure, relationship with school and parents, leadership, society and school relationship. Moreover, administrator teaches for few hours (Eurodice) [24]. In France, local authorities choose the administrators to primary schools and two-year teaching experience is required. Teachers having two-year experience is pre-evaluated by National Investigator for Education (IEN) and if accepted, their paperwork is sent to Board of Interview of the Educational Region. The board consisting of a regional and a national educational supervisor and a school administrator assesses the 
applications and calls the candidates after an interview. Teachers joining an interview previously or becoming an administrator to a school for at least one year exclude the interview for three years. But if they have applied before and been not accepted, the candidates have to reapply. Administrator is appointed for one year, if found successful by local authorities, they are reappointed for another one year (Eurydice, Europedia) [24 -25].

Whereas Regional Investigation Academy regulates the choosing and appointing process of administrators to primary schools, Ministry of Education (Recteur) is responsible for high school appointments. Teachers have to be at least 30 years old and have at least five-year teaching experience to be an administrator to a high school. Since 2007, the law code 8 gives more authorisation and responsibility to high school administrator compared to primary school administrators. Therefore, not just training but also appointing process is managed meticulously. Appointing to the position, administrators also have on-the-job training (Eurydice) [25].

The training and appointing process begins presenting with a portfolio of the candidates including their experience and a reference letter by the administrators of the school where they work. If the application is accepted, the candidate has an entry exam and an interview and lastly makes a presentation. When a candidate succeeds, he/she is appointed as a vice administrator. This is called as a training period and helps administrator gain experience. The training period lasts two years in the light of consultancy of the administrator of that school. It covers school organisation, human resources, legal and financial issues. This is the last assessment step to be an administrator as well (Eurydice) [25].

The consultant administrator (mentor) of the school where the candidates are trained has also a 3-day orientation course in the Academy. These mentors play a vital role in training the elected administrators Training period continues for 4-6 weeks in the target school. Another training period is in a state office out of field of education for 2 weeks. Mentors are very active through this period and responsible for providing the candidates program content and determining the place where they are going to be trained (Huber, 2003 as cited in Balyer \& Gündüz, ) [7].

In France, there is a mechanism controlling all these stages. The regional academy boards consisting of experts in education have the responsibility to organise training programs, hold seminars, take expertise support, organise mentors, assess and investigate. An annual nationwide meeting is hold to coordinate regional boards (Huber, 2003 as cited in Balyer \& Gündüz, 2011) [7]. School administrators can also join short term training course enabling knowledge and experience. These courses aren't obligatory but attending administrators are preferred in the processes of school and task or level changing (Lafond \& Helt) [26].

\subsubsection{Educational Leader Training and Appointing in Finland}

In Finland, school principle training and employing process is different from United States, England and France. School principals have broad powers in Finland where lifelong learning is seriously considered. School principal has the power to make curriculum, annual plan, course programmes and content. Being both education leaders and administrators of the school, School principals play a bridging role between the school and environment. Since the principles have responsibilities and powers above, choosing and appointing process is naturally carried out meticulously (OECD) [27].

Teaching experience isn't, though, a pre-condition for the principal position in Finland, usually experienced teachers are employed as school principals. Yet, it is obligatory to have education of school administration (Taipale) [28]. Two different training programmes are conducted, one of which is before appointing and the other one is when employed as a principal. The first requirement is to graduate from department of education administration of universities, which is equal to 25 ECTS and includes school laws, administration and leadership. The second one is to have a 20-45 hour and 12-ECTS certificate of education administration under the law 43/011/2000 of National Board Of Education. This programme covers public law, national and local government, education finance and human resources management and aims to train school principals before the duty. Before-job training doesn't have any practical school training as all applicants are vice principals at schools (Taipale) [28]. However, having master degree in education administration and teaching experience are very significant. In Finland, twenty 35 -ECTS doctoral programmes nationwide raise competitive administrators (Alava, Ministry of Education) [29-30].

As lifelong learning is seen important, school principals in Finland continue their training in the service. Different courses given by National Centre for Professional Development in Education (OPEKO) are financially supported by National Board of Education. Almost 200 principals join these programmes annually. This programme covers administration in education, organisation, finance, staff management, strategic planning, learning atmosphere and learning outcomes. Another training programme is workshop groups led by National Board of Education. These groups meet either in the term or in summer and principal exchange experience on new learning atmospheres, information technologies, assessment process, strategic leadership, mentorship and variable topics beneficial to students. National Board of Education, at times, provides courses to the principals if needed (Alava, Ministry of Education) [29-30].

In Finland, it is needed to attend an education administration programme. The country is made up of six states and has a lot regional programmes enabling teachers to benefit. Along with the education administration programmes at universities, certificate programmes by 
National Board of Education, OPEKO and workshops, candidates participate "Expertise in Administration Competency Programme" and have an exam so as to be a school principal. This regional expertise programme is paid, theoretical and lasts 14-16 days for the purpose of getting 40 credits. The programme charges $€ 3000-3500$ (Alava) [29].

\subsection{Education Administrator Training and Appointing in Developing Countries}

In this section, it was compared that school leaders' training and appointing process in Turkey and countries such as Bulgaria, Poland, Hungary and Portugal thought similar to Turkey. OECD facts of 2015 were considered to choose these countries. Chosen countries except for Bulgaria have a \$10.000-22.500 of Gross National Income. The same countries spend \$ 4.000 - 7.000 per capita on education (OECD)[32]. Bulgaria was included on account of having a similar GNI (\$ 7.000) though it is not in OECD facts.

\subsubsection{Educational Leader Training and Appointing in Bulgaria}

Over the past 20 years, Bulgaria has enforced reforms about a lot of education-related topics. In addition to these reforms, some change seeking projects were also tried to be started over some topics such as organisational climate, school environment related to school principals. These reforms since 2005 has resulted in some significant changes in the country's education system, both of which are decentralized administration of education and school principals' autonomy (Parvanova) [32]. To ensure the autonomy of principals, some powers such as budget management, teacher choice and cooperation with different outer organisations were granted to them. Yet, assessment of principals' competency has been ignored (Parvanova) [32].

The country has got master degree education of school administration but this is not a pre-condition to be appointed as a school principal. Continuous improvement training programmes for high school principals is provided. These 5-day programmes which are not a pre-condition to be a principal are hold by National Education Institute and participating is voluntary after the appointment. The only requirement to be a principal is 2-year teaching experience (Eurydice) [33].

In Bulgaria, Public General Education Law (Law no 37) regulates education leaders' training and appointing. Conditions to be an education leader are listed below:

1. Schools and related departments are managed by principals

2. To be a school principal, university degree and teaching experience are obligatory whereas college degree and teaching experience are accepted.
3. Ministry of National Education (MoNE) holds a competition whereby candidates present their programmes to improve the target school. The improvement programmes have to be compatible with the laws.

4. MoNE forms a commission consisting of teacher representatives and local authorities. They listen to the candidate and decide to sign a contract or not.

5. MoNE is the only authority to resign or to end up the contract.

6. Principal contract in Nursery Schools is activated by local authorities.

7. Ministers appoint principals for 5 years

8. Principal decisions are only reversed by MoNE.

9. Candidates have to be successful at the competition hold by the ministry. Yet is a common belief among people that political view is an effective factor rather than competency and merit (Eurydice) [33].

\subsubsection{Educational Leader Training and Appointing in Poland}

Poland is another country to have had fundamental changes in the field of education in 1989. The system which had been central and closed transformed to an open and regional one (Bogaj et. al.) [34]. The contemporary change in education system of Poland has aimed to raise principals competent in pedagogy, adult education, student problems and curriculum as well as financial and managerial skills (Michalak) [35]. The expected outcome was that this new holistic approach in education administration would contribute to improving individual, professional and communication skills of school principals (Ekiert-Grabowska) [36].

In Poland, improving leadership skills is seen an obligation rather than a chance in order to be a school principal. There are two methods to train school leaders. The former is to have master degree at education administration from universities or academies; the latter is to participate in leadership courses in regional in-service centres. Universities play an important role in training education leaders since Poland makes having master degree obligatory to be a principal. The goals of post graduate education are described as below (Dyrada \& Przybylska) [37];

1. Improving organisation managing skills

2. Curriculum management

3. Performance, organisation peace, innovation in education, use of technology

4. Communication with other counterparts such as government and parents.

However, continuous in-service professional training is not obligatory in Poland though it is in a number of European countries (EU Leadership in Education, Country Reports) [39]. The law called Education System Law passed in 2001 regulates conditions for appointment of school leaders. Conditions to be a school principal are stated as below; 
1. To meet the conditions for being a teacher (Master of Education).

2. Post graduate degree of education administration.

3. 5-year teaching experience.

4. School principals are appointed for 1 year to 5 year by a commission consisted by 2 members from school administration, 2 from local authority responsible for education, 2 from council of teachers in the school the candidate wants to be appointed, and lastly 2 members from School-Parent Union (Dyrada \& Przybylska, Smoczyńska) [37-38]

\subsubsection{Education Leader Training and Appointing in Portugal}

In Portugal, 1999 was the year when law on school management was modified significantly. With this change, parents, local government, teachers, students, security and other staff who had limited role in education policy got more active, thus developing a cooperative perspective (EU Leadership in Education, Country Reports) [40]. Education leader training rests on master degree in the country since one of the pre-conditions to be a school master is to have a master degree.

Continuous training programs are necessarily important because the principals fulfilling these programs successfully can progress in their careers (transition to high school administration position from that of primary school) and get salary rising (EU Leadership in Education, Country Reports) [40]. In Portugal, school councils choose the principals. The conditions to be a principal are as below;

1. At least five-year teaching experience.

2. Being educated in the field of administration, especially in of education.

3. To present an administration project.

\subsubsection{Education Leader Training and Appointing in Hungary}

In the year of 1996, Hungary had significant changes in education system. With the change, having master degree of education administration was a pre-condition in addition to graduating from a school of education. The master degree lasts four semesters and requires 360-hour training. Moreover, it involves courses of strategy, pedagogy, organisation skills, human factor, economy and law. Candidates have to pass 2 different exams and write a graduation thesis. Budapest University of Technology and Economics (BME) and Hungarian-Netherlands School of Educational Management (HUNSEM) are two important institutes in this field (EU Leadership in Education, Country Reports) [41].

In Hungary, rights of school principals were regulated by a law (no 138) in 1992. Later in1993 and in 2001, some improvements were also made. According to this law, a teacher has to have a master degree mentioned above and five-year teaching experience (Act LXXIX of 1993 on Public Education). Furthermore, continuous in-service professional courses are obligatory for school principals (EU Leadership in Education, Country Reports) [41].

\subsubsection{Education Leader Training and Appointing in Turkey}

Although education leader training in Turkey has been an issue debated on and taken precautions, it is still not a solved problem today. Established in 1953, Institute of Public Administration for Turkey and the Middle East was the first official institute to signify the education of school leaders. Another state office "Managing Board of the Central Government Organization Research Project" stated in a report of 1962 that education administration needed expertise and universities must have departments of education administration (Cemaloğlu) [42].

Opened in 1965, Ankara University, Faculty of Educational Sciences educated students for the first time at undergraduate level. In following years, a number of universities opened departments for the purpose of raising education leaders but since graduates didn't have privileges and weren't appointed as education leaders, these departments at undergraduate level were closed in 1997 on grounds that they were non-functional. Today, universities have departments of educational administration but graduating from these departments isn't a pre-condition to be appointed as a school principal although over 30 official regulations were published and criteria for appointments were often changed (Altın \& Vatanartıran) [6] .

The regulation no 23472 on education administrators' appointing and appointment in MoNE can be seen as a regulation which considers merit because the candidates have to pass an exam hold by official Assessment Selection and Placement Centre (ÖSYM) in order to be a principal. The candidates need to have 80 for type A positions, 75 for type $\mathrm{B}$ and 70 for type $\mathrm{C}$ positions. They also have 120-hour, obligatory in-service training courses. However, those having master degree of education administration, public administration master from Institute of Public Administration for Turkey and the Middle East and 5-year teaching experience exclude from the exam and are directly taken in-service training. According to that regulation, candidates getting 70 and over from the in-service training are appointed.

As of 1998 to 2017, Turkey's governments have ignored merit for the appointment of administrators. Because, 18 years ago, there was a central written exam and teachers having master degree at educational and public administration, 5-year teaching experience were preferential but today, school principals are appointed by a subjective interview. Turkey has moved into a system of interview from a system that teachers having master degree at educational and public administration, 5-year teaching experience were preferential. This transformation clearly shows that school leaders' training has been pushed into the background. According to the last regulation no 29494 published in 2015, candidates have to possess requisite qualifications below;

1. Working as an administrator

2. At least two-year experience in the position of senior vice principal 
3. At least three-year experience as founding manager, senior vice principal or vice principal separately or totally.

4. To work as unit head or above in MoNE.

Teachers possessing conditions above enter a written and oral exam if they succeed; they are appointed as a teacher. It is not obligatory for teachers to have in-service training before the exam or appointment.

The fundamental change to appoint school principal was in regulation no 29026 of 2014 and 29294 of 2015 because appointments of principals are done according to the results of oral exams rather than exam result supremacy in previous regulations. With these regulations training education leaders are totally ignored. Although MoNE holds about-5-day courses these courses don't bring school principals any benefit such as promotion to an upper level, privileges for some tasks or economical contribution.

Subjective oral exams and ignorance of training process naturally brought a lot of objections. Because principals are removed from their offices and new principals are appointed after so-called oral exams, a number of trials with claims of ignorance of merit or cronyism and political favouritism continue. Some labour unions also give their members legal support.

Table 1 at the end of the study (Appendix 1) shows the differences and similarities the target countries in terms of assigning school leaders.

\section{Conclusions}

In this study, some developed countries such as England, the UNITED STATES, France and Finland and some developing countries such as Bulgaria, Poland, Hungary and Turkey were observed and compared in terms of education leader training and appointing processes. As seen in the study, Training and appointing processes in developed countries are closely related to those countries' public administration. In England, the United States, and Finland, training and appointing are governed regionally as these countries have a decentralized system. Moreover schools have the rights to speak through the process. These countries have an accountable and transparent training and appointing framework. Therefore, choosing and appointing processes are in no uncertain words. France has central structure and the processes are managed by MoNE but it varies by school type. While primary school principals are responsible to the regional education authority, the Regional Auditing Academy, the Ministry of Education (Recteur) is responsible for the appointment of secondary school principals. For this reason, a decentralized process is followed during the process of selecting and appointing the school principal, and the examinations and appointments are carried out by the Ministry of Education. So as to be a school principal in the UK in the scope of this study, it is on the basis of the National School Principals Standards, incorporating theory and practice, and requires being involved in a training program that plays an active role in the development of managerial skills. In order to become a school principal in United States, it is stated that he/she is required to have a master degree in Educational Administration or to pursue any master degree. Candidates having any master degree must also have taken 18 hours of basic education administration courses. In France, primary education principals do not have an obligatory pre-service training. However, the internship, which is an important part of the training of principals, provides for two-year on-the-job training for candidates to gain experience and specialize in school administration, In order to become a school principal in Finland, he/she must be trained in school administration before and during the service period. In developed countries, which are covered in this study, as competitive policies and lifelong learning have developed, school principals can be involved in in-service training during their service life. These in-service courses, funded by the school or individual allowances already in place, provide the development of professional knowledge and skills as well as individual skills. Thus, holistic development is aimed to adapt to new developments. Graduating from any higher education program is required in order to be a school principal in Finland, while, in developed countries, it is required to be a teacher to become a school principal in England, United States and France, and to have two to five years of experience in the profession. In Finland, It is not necessary to have a teaching experience in order to become a school principal, but a candidate manager must have completed his education in school administration.

Looking at Bulgaria, Poland and Hungary from developing countries, it is pointed out that reforms in the field of education have been carried out and they have to be included in a training program in education management in order to become school principals in these countries. The issue of how schools should be managed in Bulgaria was reviewed again, and in 2005, school principals were given autonomy, and many school decisions were left to the discretion of school heads. A graduate education and in-service training program to become a school principal in Bulgaria is not considered a prerequisite for being a school head.

Being a university graduate and having two years teaching experience is a prerequisite. Candidates carrying this prerequisite are taken to the central school management examination carried out by the MoNE and the exam is conducted by local administrators of the region. Successful candidates are employed by signing a five-year contract. The contract signed with school principals can be ended before the process is over. There is widespread belief that political viewpoint is influential in managerial appointments in Bulgaria, where experience and competence in school principals' referral is not a priority.

In Poland, with the influence of changing global dynamics, it has entered into drastic changes in education and has begun to adopt a new holistic structure. According 
to this structure, it is envisaged that the school principals who will expose the managerial function in the school should firstly develop the leadership qualities, as well as the financial, managerial and educational activities. In the country, in order to be a school manager different from Bulgaria, it is necessary to have a master's degree in educational administration and have at least five years of teaching experience. In Poland, the appointment of school principals is made for processes ranging from 1-5 years by a board of school and local administrators.

In Hungary, managerial training policies were abandoned from a single center and school autonomy gained importance. In Hungary, school management boards are the decision-making mechanism in the process of appointing school principals. In order to be a school principal in a school, it is necessary to have a master's degree in educational administration and have 5 years teaching experience.

On the other hand, understanding of "education administration is a profession" espoused in developed countries is ignored in view of the fact that in Turkey the concepts of "basic teacher in profession" and "absence of school of administration" prevail.

It is seen that Education Administration and planning departments in Turkey were active at the undergraduate level, from 1970 to 1997, in which a school leader training model is applied. However, candidates graduated from such program covering topics such as the organization, administration, leadership, and education planning, were mostly not employed.

In the 1997-1998 academic year, with the provision that it is possible to become a teacher for people who graduated from many areas (veterinary, agricultural, engineering faculties, fisheries, law, political, economy and administrative sciences etc.), Most candidates who have graduated from the Department of Education Management and Planning (in some universities, in the name of Education Management, Planning, Inspection and Economy) have also been employed as teachers. In other words, school leaders training programs are closed at the undergraduate level with the reason that no training is needed. Today, graduate programs in education management in Turkey are continuing their education and training activities, but graduates from this department are not employed as an education administrator. However, some of the graduates continue to work as teachers or academicians while some of them are employed in irrelevant areas. In this context, it is seen that the administration training period has been abolished and the conditions for being a teacher and being able to exceed the managerial examination threshold are sufficient to be able to work as a principal in a school. Over the past ten years, more than thirty regulations have been issued in Turkey concerning the selection and appointment of administrators, and the time spent in teaching has been gradually reduced in each regulation change. It is noteworthy that with the new legislation introduced in 2015 and with the regulation on appointment according to the results of the oral examinations, the conditions of merit are totally ignored. At the same time, it is a constantly spoken issue that the decisions of the political authority are overtaken in the process of the appointment of school principals, change of office or termination of office.

When there is a comparison between developed and developing countries, there is not a process called "administrator training" in Turkey, which is the first to attract attention. Although programs at the master's and doctoral levels. These are not required in the appointment of administrators as in Bulgaria. In developed countries, it is noteworthy that managerial training and appointment processes are clearly defined and there is stability in this issue. Looking at the developing countries in the scope of the research, it is seen that others except Bulgaria have a process of training and appointing a principal. Another point to note is that in the developed countries, the designation of the merit is in the process of appointment and that there are no problems in this regard. Yet, Political weight is seen in the process of appointment in Turkey Poland and Bulgaria. Particularly, in Turkey in the last decade, the non-objective appointment process and the complete obfuscation of the training period have brought many objections. Many lawsuits are still continuing with the alleged lack of merit and favoritism due to the termination of the duties of many of the examiners and the appointment of those close to the political power with interview exams. It can be said that the process of raising and appointing school principals in Turkey should be done more diligently after attempted coup on July 15th. After July 15th, thousands of people were dismissed in all sectors, especially in the education sector. This process is still going on. Education is the area where the majority of the employees are fired. Thousands of employees have been removed from their jobs at every level from basic education to university.

It is a fact that educational institutions are known to be important to educating people with a certain mind that has an impact on the future of the country. It is possible with the people of a country that is equipped with good citizenship and good human characteristics depending on the values of the management understanding of the future country. For this reason, the training, selection and appointment of education leaders who will be responsible for the management of this process seems to be very important. In the light of this information, it can be said that Turkey is behind the developed and developing countries in the process of training, selection and appointment of the education leaders and these processes are mostly carried out according to political decisions. In this context, in order to solve many problems in the field of education, it is necessary to make an objective and stable arrangement which is far from political pressures in the process of raising, selecting and appointing an education administrator for the bright future of the country. 


\section{Appendix}

Comparison of Assigning of School Leaders

\begin{tabular}{|c|c|c|c|c|}
\hline Country & & $\begin{array}{l}\text { Master in Education } \\
\text { Managemement }\end{array}$ & In-Service Training & $\begin{array}{l}\text { Presenting a Project about } \\
\text { Target School }\end{array}$ \\
\hline UK & at least 5 years & not compulsory & compulsory & not compulsory \\
\hline France & $\begin{array}{c}\text { at least } 2 \text { years for primary } \\
\text { and } 5 \text { years for secondary } \\
\text { schools }\end{array}$ & not compulsory & compulsory & not compulsory \\
\hline $\begin{array}{l}\text { United } \\
\text { States }\end{array}$ & $1-3$ years & compulsory (in any field) & compulsory & not compulsory \\
\hline Finland & not compulsory & not compulsory & compulsory & not compulsory \\
\hline Bulgaria & at least 2 years & not compulsory & not compulsory & $\begin{array}{l}\text { Compulsory (but political } \\
\text { view influental according } \\
\text { to EU reports) }\end{array}$ \\
\hline Poland & a tleast 5 years & $\begin{array}{c}\text { compulsory (master in education } \\
\text { management) }\end{array}$ & not compulsory & not compulsory \\
\hline Portugal & at least 5 years & $\begin{array}{c}\text { compulsory (management - esp. } \\
\text { education management) }\end{array}$ & $\begin{array}{l}\text { provides upper positions and } \\
\text { salary increase }\end{array}$ & compulsory \\
\hline Hungary & at least 5 years & $\begin{array}{c}\text { compulsory (education management } \\
\text { and leadership) }\end{array}$ & $\begin{array}{l}\text { not compulsory to be } \\
\text { assigned but attendance } \\
\text { compulsory incareer }\end{array}$ & not compulsory \\
\hline Turkey & at least 3 years & not compulsory & not compulsory & not compulsory \\
\hline
\end{tabular}

\section{REFERENCES}

[1] M. C. DeVita, R. L Colvin, L. Darling-Hammond, K. Haycock. Education leadership: A bridge to school reform, The Wallace Foundation, New York, 2007.

[2] A. W. Jackson, G. A. Davis. Turning Points 2000: Educating Adolescents in the 21 st Century, Teachers College Press \& National Middle School Association. New York \& Westerville, $\mathrm{OH}, 2000$.

[3] L. Olson. Policy focus converges on leadership. Education Week, XIX, Vol. 19, 2000.

[4] F. Khan, R.M. Yusoff, A. Khan. Job demands, burnout and resources in teaching a conceptual review. World Applied Sciences Journal, Vol.30, No.1, 20-28, 2014.

[5] L. Mitgang. The making of the principal: Five lessons in leadership training perspective. Wallace Foundation, 2012.

[6] F. Altın, S. Vatanarttıran. Türkiye'de okul yöneticisi yetiştirme, atama ve sürekli geliştirme model önerisi. Ahi Evran Üniversitesi Kırşehir Eğitim Fakültesi Dergisi, Vol.15, No.2, 2014.

[7] A. Balyer, Y. Gündüz. Değişik ülkelerde okul müdürlerinin yetiştirilmesi: Türk eğitim systemi için bir model önerisi. Kuramsal Eğitim Bilim, Vol.4, No.2, 182-197, 2011.

[8] L. Cohen, L. Manion, K. Morrison. Research methods in education (5 th) Taylor \& Francis e-library. UK. 2005.

[9] Ş. Büyüköztürk, E.K. Çakmak, Ö. E. Akgün, Ş. Karadeniz, F. Demirel. Bilimsel araştırma yöntemleri. Pegem Akademi. Ankara, 2008

[10] A Yıldırım, H. Şimşek, Sosyal bilimlerde nitel araştırma yöntemleri, Seçkin Yayınları, Ankara, 2008.
[11] DfES (Department for Education and Skills), National standards for head teachers, reference 0083/2004, Department for Education and Skills Online available: from http://www3.nccu.edu.tw/ mujinc/teaching/9-101 principal/re fer4 2(24\%20national\%20standards)

[12] R. Bolam. Reflections on the NCSL from a historical perspective. Educational Management Administration \& Leadership, Vol.32, No.3, 251-267, 2004.

[13] NPQH. National Professional Qualification for Headship: Online Available from https://www.gov.uk/guidance/nationa 1-professional-qualification-for-headship-npqh

[14] NPBEA. National Policy Board for Educational Administration: Online Available from http://www.ccsso.org/Documents/2015/ProfessionalStandards forEducationalLeaders2015forNPBEAFINAL.pdf

[15] NCLS (National College for Leadership). Recruiting head teachers and senior leaders: Online available from http://dera.ioe.ac.uk/6978/1/download\%3Fid\%3D17347\%26f ilename $\% 3$ Drecruiting-headteachers-and-senior-leaders-fullguidance.pdf

[16] SAT (Specialist Schools and Academies Trust): Online Available from https://www.ssatuk.co.uk/

[17] E. L. Hale, H. N. Moorman. Preparing school principals: A national perspective on policy and program innovations. Institute for Educational Leadership (NJ1), Institute for Educational Leadership, Education Research Council, Washington, DC and Illinois Edwardsville, IL, 2003.

[18] A. W. Jackson, G. A. Davis. Turning Points 2000: Educating Adolescents in the 21st Century., OH: Teachers College Press \& National Middle School Association, New York \& Westerville, 2000.

[19] R. A. Edelfelt. VGM. Professional Career: Careers in Education Horizons, McGrow Hill, Illinois, UNITTED STATES, 1992. 
[20] Bureau of Labor Statistics. Occupational Outlook Handbook: Online Available from http://www.credentialwatch.org/occ/2010-110OH.pdf

[21] A. Schleicher. Preparing teachers and developing school leaders for the 21st century: Lessons from around the world. ERIC, 2012.

[22] K. Meclntyre. Training programs for principals, Theory into Practice. Vol. 18, No.1, 28-32, 2001.

[23] M.E. Anderson, Principals: How to train, recruit, select, induct, and evaluate leaders for America's schools. ERIC, 1991.

[24] Eurydice. Organization of the education system in France [Cited 2017 March, 24]: Online available from https://estudandoeducacao.files.wordpress.com/2011/05/franc 3a7a.pdf

[25] Europedia. France [cited 2017 March, 24]: Online available from

https://webgate.ec.europa.eu/fpfis/mwikis/eurydice/index.php /France:Overview

[26] A Lafond, J. P. Helt. The appointment and training of head teachers in France. In selecting and developing heads of schools: twenty-three European perspectives. Sheffield: European Forum on Educational Administration, 2003.

[27] OECD. School leadership for systemic improvement in Finland [cited 2017 March, 25]: Online available from https://www.oecd.org/edu/school/39928629.pdf

[28] A. Taipale. International survey on educational leadership. A Survey on School Leader's Work and Continuing Education. Finnish National Board of Education, 2012.

[29] Alava, J. School management training. country reports: Finland. Studies in Education Management Research, Vol. 31, 2007.

[30] Ministry of Education. Improving school leadership in Finland. Department for education and science [cited 2017 March, 25]: Online Available from https://www.oecd.org/edu /school/38529249.pdf

[31] OECD. Gross national income. [cited 2017 March, 25]: Online Available from https://data.oecd.org/natincome/gross-national-income.htm
[32] Y. Parvanova. School management and school evaluation. a comparative analysis of Bulgarian and Japanese experience, Sofia University Journal of Educational Research, Vol. 1, No, 3-4, 2013.

[33] Eurydice. Leadership in education, country background report, Bulgaria. [ cited 2017, March 20]: Online Available from http://www.leadership-in-education.eu/fileadmin/reports/CR BG.pdf

[34] A. Bogaj, K. Kafel, S. M. Kwiatkowski, R.Piwowarski, Education for all: The year 2000 assessment. Institute for Educational Research, Warsaw, 2000.

[35] J. M. Michalak. Making a difference in challenging urban schools: successful principals. European Educational Research Journal, Vol. 8, No. 3, 387-396, 2007.

[36] D. Ekiert-Grabowska, D. Oldroyd. Nowoczesne tendencje w kształceniu oświatowych kadr kierowniczych w Polsce i Wielkiej Brytanii. Katowice, 1998.

[37] B. Dyrda, I. Przybylska. Dimensions of the Role of the Head Teacher in the Educational System in Poland. The New Educational Review, Vol. 16, No. 3-4, 126-136, 2008.

[38] A. Smoczyńska, M. Górowska-Fells, B. Maluchnik, B. Platos, M. Chojnacki, M. Smolik. The system of education in Poland. Warsaw: The Polish Eurydice Unit, 2014.

[39] European Union. Leadership in education, country reports/Poland. [Cited 2017, January 22]: Online Available from

http://www.leadershipeducation.eu/fileadmin/reports/CR_PL. pdf

[40] European Union. Leadership in education, country reports / Portugal. [cited: 2017, January 15]: Online Available from http://www.leadership-in-education.eu/fileadmin/reports/CR PT.pdf

[41] European Union. Leadership in education, country reports / Hungary. [Cited 2017, January 15]: Online Available from http://www.leadership-in-education. eu/fileadmin/reports/CR_HU.pdf

[42] N. Cemaloğlu. Türkiye'de okul yöneticisi yetiştirme ve istihdamı: Var olan durum, gelecekteki olası gelişmeler ve sorunlar. Gazi Eğitim Fakültesi Dergisi, Vol.25, No.2, 249-274, 2005. 